DOI: https://doi.org/10.24127/ajpm.v10i2.3331

\title{
PENGEMBANGAN PERANGKAT PEMBELAJARAN MODEL PROBLEM BASED LEARNING TERINTEGRASI KETERAMPILAN ABAD 21
}

\author{
Reni Yanuarni ${ }^{1}$, Putri Yuanita ${ }^{2^{*}}$, Maimunah $^{3}$ \\ ${ }^{1,2,3}$ Universitas Riau, Pekanbaru, Indonesia \\ *Corresponding author \\ E-mail: \\ reni.yanuarni6292@grad.unri.ac.id ${ }^{1)}$ \\ putri.yuanita@lecturer.unri.ac.id ${ }^{2 *}$ \\ maimunah@lecturer.unri.ac.id ${ }^{3)}$
}

Received 01 December 2020; Received in revised form 27 February 2021; Accepted 09 June 2021

\begin{abstract}
Abstrak
Tujuan penelitian ini adalah menghasilkan perangkat pembelajaran melalui penerapan model Problem Based Learning terintegrasi keterampilan Abad 21 untuk peserta didik kelas X SMA yang memenuhi kriteria valid dan praktis. Penelitian ini adalah penelitian pengembangan yang menggunakan model Plomp. Penelitian ini terdiri dari tiga fase yaitu: (1) fase investigasi awal (preliminary research); (2) fase prototipe (prototyping phase); dan (3) fase penilaian (assessment phase). Perangkat pembelajaran yang dikembangkan yaitu silabus, RPP, dan LKPD yang divalidasi oleh tiga validator, uji coba terbatas dilakukan pada enam peserta didik kelas X SMAN 15 Pekanbaru. Hasil validasi dari ketiga validator menyatakan bahwa perangkat pembelajaran adalah valid dengan rata-rata 3,40 untuk silabus; 3,49 untuk RPP; 3,52 untuk LKPD; 3,46 untuk soal kemampuan berpikir kreatif, hasil angket respon peserta didik terhadap LKPD yaitu 87,04\%. Berdasarkan hasil penelitian disimpulkan bahwa perangkat pembelajaran berbasis keterampilan abad 21 dengan penerapan model Problem Based Learning untuk peserta didik pada materi aturan sinus dan cosinus kelas X SMA dinyatakan sangat valid dan sangat praktis.
\end{abstract}

Kata kunci: Keterampilan abad 21; model problem based learning; perangkat pembelajaran.

\begin{abstract}
The purpose of this study was to produce learning tools through the application of the integrated problem-based learning model of 21st century skills of class X SMA students that occupy valid and practical criteria. This research is a development research using the Plomp model. The learning tools developed were syllabus, lesson plan and student worksheet which were validated by three validators, limited trials were carried out on six students of class X SMAN 15 Pekanbaru. The results of the validation of the three validators stated that the learning device was valid with an average of 3.40 for the syllabus; 3.49 for RPP; 3.52 for LKPD; 3.46 for the question of creative thinking skills, the results of the student response questionnaire to LKPD were $87.04 \%$. Based on the results of the study, it was concluded that the 21st century skill-based learning tools with the application of Problem Based Learning models in the material of the rules of the sine and cosine rules of class X SMA were declared very valid and very practical.
\end{abstract}

Keywords: 21st century skills; learning tools; problem based learning models.

This is an open access article under the Creative Commons Attribution 4.0 International License

\section{PENDAHULUAN}

Abad 21 menuntut setiap individu untuk memiliki kecakapan atau keterampilan, mampu menjalin suatu kolaborasi, memiliki pola fikir kritis dan kreatif, memiliki keterampilan belajar dan berinovasi, serta terampil menggunakan teknologi dan informasi, serta dapat bekerja dan bertahan hidup menggunakan kecakapan yang mereka miliki. Keterampilan ini tidak dimiliki seseorang sejak lahir, melainkan 
melainkan melalui proses latihan, belajar, atau pengalaman.

Redhana (2019) mengatakan bahwa penyiapan sumber daya manusia yang menguasai keterampilan abad 21 akan efektif jika ditempuh melalui jalur pendidikan. Menurut Putri, Kartini, \& Yuanita (2020) dalam era globalisasi, guru harus memotivasi, mendorong, dan memfasilitasi siswanya membangun pengetahuannya dalam proses pembelajaran. Namun, guru bukan lagi sumber utama belajar.

Susianna (2014) dalam penelitiannya menyatakan bahwa $48 \%$ guru belum merancang, menerapkan dan mengaplikasikan keterampilan abad 21 dalam pembelajaran. Berdasarkan hasil wawancara yang dilakukan, diperoleh informasi bahwa guru mengalami kesulitan dalam menyusun perangkat pembelajaran kurikulum 2013, terutama perangkat pembelajaran yang menerapkan model-model pembelajaran inovatif.

Kenyataan pada pembelajaran di sekolah, peserta didik belum semua mendapatkan keterampilan abad 21 . Salah satu keterampilan abad 21 yang harus dimiliki peserta didik adalah kemampuan berpikir kreatif. Menurut Supardi (2015) kreativitas seseorang akan mempengaruhi hasil belajarnya. Peserta didik dengan kreativitas yang tinggi lebih menonjol prestasi belajarnya dibanding peserta didik dengan kreativitas yang rendah. Hal ini juga sejalan dengan penelitian Suriyani (2015) menyatakan bahwa pengembangan kemampuan berfikir kreatif memang perlu dilakukan karena kemampuan ini merupakan salah satu kemampuan yang dikehendaki dunia kerja. Tidak diragukan lagi bahwa kemampuan berpikir kraetif juga menjadi penentu keunggulan suatu bangsa. Hal ini juga sejalan menurut
Maimunah, Yuanita, \& Solfitri (2017) bahwa aktivitas berpikir ini melibatkan pengsintesisan ide-ide, pembangunan ide-ide, perencanaan penerapan ide-ide, dan penerapan ide-ide tersebut.

Dari hasil studi awal tes kemampuan berpikir kreatif yang telah dilakukan, dari 20 peserta didik hanya $40 \%$ yang memenuhi indikator fleksibel dan kefasihan, $20 \%$ peserta didik memenuhi indikator kebaruan. Hal ini menunjukkan bahwa kemampuan berpikir kreatif peserta didik masih rendah. Rendahnya kemampuan berpikir kreatif peserta didik juga ditunjukkan dari hasil tes Programme for International Student Assesment (PISA) pada tahun 2015. Fakta yang ditemukan 32\% peserta didik tidak dapat menyelesaikan soal matematika bahkan dalam kategori yang paling mudah. Menurut Bidasari (2017) soal Matematika PISA dapat digunakan sebagai tolok ukur terhadap kemampuan berpikir kreatif matematis peserta didik, karena soal PISA juga menuntut kemampuan berpikir kreatif.

Cara yang dapat dilakukan untuk meningkatkan kemampuan berpikir kreatif peserta didik yaitu dengan memperbaiki pelaksanaan kegiatan pembelajaran. Kegiatan pembelajaran meliputi kegiatan persiapan pembelajaran, pelaksanaan, dan evaluasi. Kegiatan pembelajaran yang baik harus diawali dengan perangkat pembelajaran yang baik. Salah satu bentuk persiapan yang harus dilakukan oleh guru dalam proses pembelajaran adalah perangkat pembelajaran (Putri, Roza, \& Maimunah, 2020). Perlu adanya inovasi pembelajaran yang berpusat pada peserta didik, pembelajaran yang memberikan kesempatan kepada peserta didik untuk dapat meningkatkan aktivitas belajar. Pembelajaran yang menerapkan model pembelajaran yang dapat memotivasi peserta didik mene- 
mukan atau memperoleh konsep melalui investigasi, penemuan, penyele-saian masalah, mendorong kemandirian belajar peserta didik dan kreatifitas yaitu model Problem Based Learning (PBL).

Rendahnya kemampuan berpikir kreatif peserta didik salah satunya pada materi Trigonometri. Trigonometri merupakan salah satu materi pembelajaran matematika yang banyak memuat hal-hal konkret dan nyata yang berhubungan dengan kehidupan sehari-hari.

Salah satu alternatif yang dapat membantu peserta didik untuk meningkatkan kemampuan berfikir kreatif pada materi Trigonometri adalah penerapan model PBL. Untuk memaksimalkan penggunaan model pembelajaran PBL, maka model PBL perlu diintegrasikan ke dalam semua perangkat pembelajaran materi Trigonometri di mana guru dapat melaksanakan pembe-lajaran yang aktif mengembangkan peserta didik sehingga dapat mening-katkan kemampuan berpikir kreatif. Model PBL merupakan salah satu model pembelajaran yang cocok untuk mengajarkan materi trigonometri karena PBL melibatkan peserta didik secara aktif untuk menghadapi permasalahan sesuai kehidupan sehari-hari. Sejalan dengan penelitian Yuan \& Sriraman (2011) menyatakan bahwa penerapan PBL dalam pembelajaran matematika menjadikan peserta didik memiliki keterampilan dalam pemecahan masalah, berpikir kreatif dan ber-pikir kritis. Hartini, Kusdiwelirawan, \& Fitriana (2014) mengatakan model PBL memberikan pengaruh terhadap prestasi belajar peserta didik dan mampu meningkatkan kemampuan berpikir kreatif.

Penelitian sebelumnya oleh Sultoni \& Agustanto (2016) tentang upaya peningkatan kemampuan berpikir kreatif dengan Problem Based Learning melalui pendekatan saintifik pada materi trigonometri, dalam penelitiannya menyimpulkan bahwa pembelajaran dengan model PBL berpendekatan saintifik mampu meningkatkan keterampilan berpikir kreatif peserta didik kelas XI MIA 4 MAN Temanggung pada materi trigonometri. Penelitian lainnya dilakukan oleh Muntaha \& Hartono (2013) di SMP Negeri 2 Jepara, Jawa Tengah melakukan penelitian tentang Pengembangan Perangkat Pembelajaran Model Problem Based Learning untuk meningkatkan kemampuan berpikir kreatif, hasil penelitiannya menyimpulkan bahwa pembelajaran dengan model PBL berbantukan $\mathrm{CD}$ pembelajaran mampu meningkatkan keterampilan berpikir kreatif peserta didik.

Perbedaan pengembangan perangkat yang dilakukan dengan penelitian yang sudah ada yaitu pada penelitian ini akan mengembangkan sebuah perangkat pembelajaran dengan penerapan model PBL yang mengintegrasikan keterampilan abad 21 untuk memfasilitasi peserta didik mengembangkan kemampuan berfikir kreatif pada materi aturan sinus dan cosinus peserta didik kelas $\mathrm{X}$ Sekolah Menengah Atas (SMA).

\section{METODE PENELITIAN}

Subjek penelitian adalah 6 orang peserta didik kelas X SMA Negeri 15 Pekanbaru. Sedangkan objek penelitian adalah perangkat pembelajaran tentang materi aturan sinus dan cosinus melalui penerapan model PBL terintegrasi keterampilan abad 21 untuk kelas $\mathrm{X}$ SMA/MA sederajat.

Jenis Penelitian yang dilakukan adalah penelitian pengembangan dengan model Plomp. Model pengembangan Plomp ini terdiri dari atas tiga tahapan/fase, yaitu (1) fase investigasi 
DOI: https://doi.org/10.24127/ajpm.v10i2.3331

awal (preliminary research); (2) fase prototipe (prototyping phase); (3) fase penilaian (assessment phase) (Nieveen,
1999). Bagan Prosedur penelitian dapat dilihat pada Gambar 1.

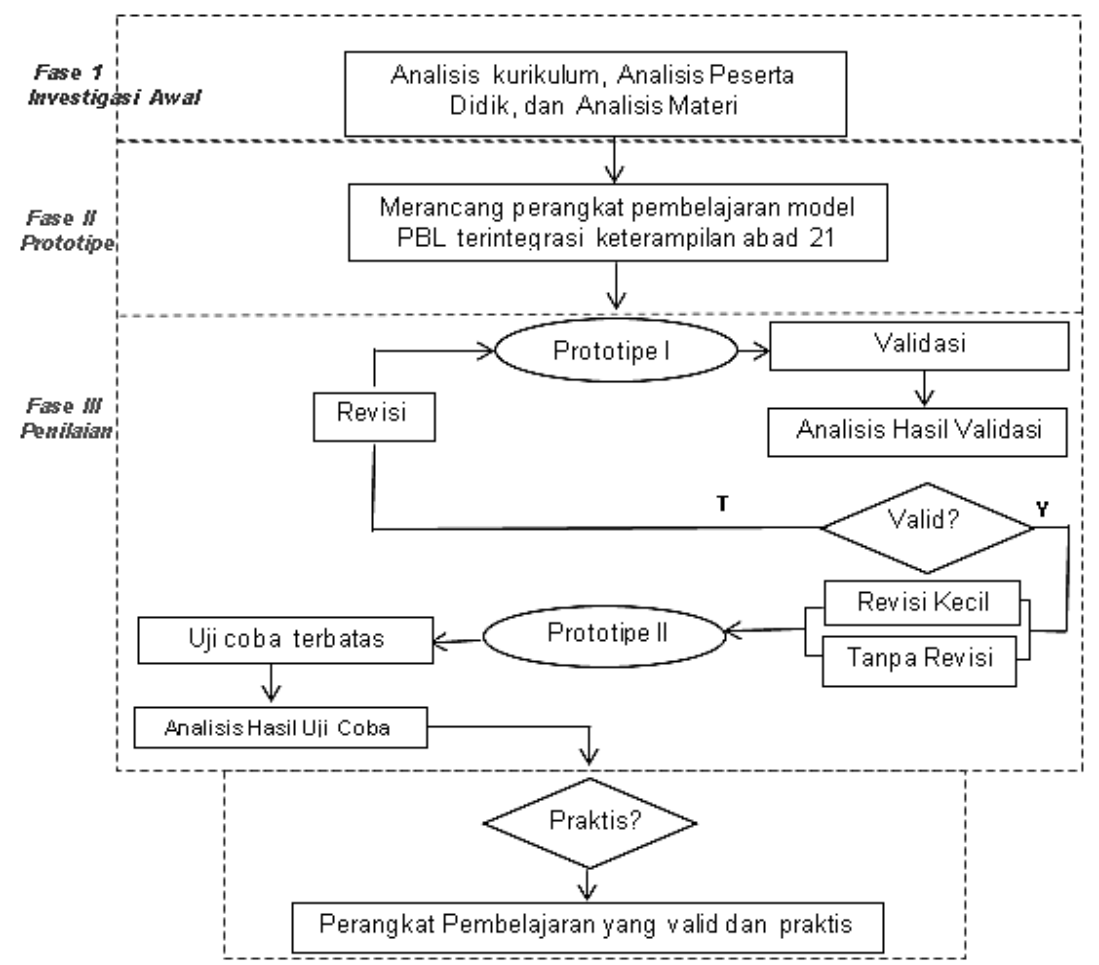

Gambar 1. Alur pengembangan perangkat pembelajaran

Pada fase investigasi awal (preliminary research) dilakukan analisis kurikulum, analisis materi dan analisis terhadap peserta didik. Pada fase prototype (prototyping phase) yang dilakukan adalah merancang perangkat pembelajaran dan memvalidasi perangkat sehingga menghasilkan prototype. Pada fase penilaian (assessment phase), dilakukan uji coba terbatas untuk melihat tingkat kepraktisan produk. Instrumen kevalidan adalah perangkat pembelajaran dalam penelitian ini adalah silabus, Rencana Pelaksanaan Pembelajaran (RPP), dan Lembar Kerja Peserta Didik (LKPD) menggunakan lembar validasi. Instrumen kepraktisan adalah angket respon peserta didik.

Analisis data yang digunakan meliputi analisis deskriptif yang mendeskripsikan validitas dan praktikalitas perangkat pembelajaran yang dikembangkan. Adapun kriteria validitas perangkat pembelajaran dapat dilihat pada Tabel 1 dan kriteria praktikalitas dapat dilihat pada Tabel 2.

Tabel 1. Kriteria validitas perangkat pembelajaran

\begin{tabular}{cc}
\hline Interval & Tingkat Kevaliditas \\
\hline $3,5 \leq \mathrm{Sr} \leq 4,0$ & Sangat Valid \\
$2,5 \leq \mathrm{Sr}<3,5$ & Valid \\
$1,5 \leq \mathrm{Sr}<2,5$ & Kurang Valid \\
$1,0 \leq \mathrm{Sr}<1,5$ & Tidak Valid \\
\hline \multicolumn{2}{c}{ (Sumber : Juniantari, 2017) } \\
Berdasarkan Tabel 1 perangkat \\
pembelajaran dikatakan valid jika nilai \\
minimum dari hasil validasi berkisar 2,5 \\
$\leq \mathrm{Sr}<3,5$. Data yang diperoleh dari \\
lembar validasi berupa komentar atau \\
saran digunakan sebagai landasan untuk \\
merevisi produk yang dikembangkan.
\end{tabular}


DOI: https://doi.org/10.24127/ajpm.v10i2.3331

Tabel 2. Kriteria penilaian praktikalitas

\begin{tabular}{cc}
\hline Interval & $\begin{array}{c}\text { Tingkat } \\
\text { praktikalitas }\end{array}$ \\
\hline $85,01 \%-100 \%$ & Sangat praktis \\
$70,01 \%-85 \%$ & Praktis \\
$50,01 \%-70 \%$ & Kurang praktis \\
$0,1 \%-50 \%$ & Tidak praktis \\
\hline \multicolumn{2}{c}{ (Sumber : Akbar, 2013) }
\end{tabular}

Berdasarkan Tabel 2 suatu perangkat pembelajaran dikatakan praktis jika persentase hasil penilaian besar dari 70\%. Produk hasil pengembangan dikatakan memenuhi aspek praktikalitas baik jika minimal tingkat kepraktisan yang dicapai adalah praktis $(70,01 \%-85 \%)$.

\section{HASIL DAN PEMBAHASAN}

Hasil penelitian yang diperoleh adalah sebagai berikut:

1. Fase Investigasi Awal (Preliminary Investigation)

Pada fase ini dilakukan analisis kurikulum yang berlaku yaitu kurikulum 2013. Pada analisis kurikulum masalah yang dihadapi adalah masih terbatasnya perangkat pembelajaran kurikulum 2013 yang sesuai Permendikbud No 22 Tahun 2016. Hasil wawancara dengan guru matematika diperoleh informasi bahwa guru belum memahami dan menerapkan model, strategi atau pendekatan yang sesuai dengan tuntutan kurukulum 2013. Selain itu guru mengalami kesulitan dalam membuat RPP yang menerapkan dan mengaplikasikan keterampilan abad 21 , sehingga masih banyak peserta didik yang belum mendapatkan keterampilan abad 21 dalam proses pembelajaran terutama keterampilan berfikir kreatif. Dalam kegiatan pembelajaran pada RPP belum melibatkan model atau strategi yang mampu meningkatkan kemampuan berfikir kreatif peserta didik dan belum menerapkan pendekatan saintifik sesuai dengan kurikulum 2013. Hal ini disebabkan guru belum memahami dan belum mampu menerapkan model, strategi maupun pendekatan yang sesuai dengan tuntutan Kurikulum 2013. Selain itu sebagian guru masih kesulitan dalam menerapkan keterampilan abad 21 dan membuat rencana penilaian pada RPP.

Guru belum memfasilitasi keterampilan abad 21 peserta didik. Kegiatan inti pembelajaran masih text book oriented dan teacher centered. Guru belum menyediakan fasilitas pengalaman belajar bagi peserta didik untuk melakukan berbagai kegiatan yang memungkinkan mereka mengembangkan kemampuan yang dimilikinya. Menurut Redhana (2019) pembelajaran yang berpusat pada peserta didik merupakan jawaban dari upaya untuk mengembangkan keterampilan abad 21 pada peserta didik.

Mayoritas guru tidak menggunakan LKPD. Guru hanya menggunakan buku sumber dari Kemendikbud. Menurut Umbaryati (2016) LKPD merupakan salah satu sarana untuk membantu dan mempermudah dalam kegiatan belajar mengajar sehingga akan terbentuk interaksi yang efektif antara peserta didik, namun di lapangan LKPD yang digunakan hanya berisi daftar pertanyaan, peserta didik diberikan jenis soal yang hanya bisa diselesaikan dengan satu cara peyelesaian. Soal dengan satu cara penyelesaian ini membatasi peserta didik untuk menemukan ide-ide yang berbeda atau kefasihan dan menghasilkan produk atau ide baru atau kebaruan. Soal-soal yang diberikan bersifat abstrak, bukan masalah-masalah kontekstual. LKPD hendaknya bukan hanya merupakan kumpulan soal-soal, akan tetapi lebih kepada bahan ajar cetak yang berisi tugas-tugas dan petunjukpetunjuk pelaksanaan tugas yang 
mengacu pada kompetensi yang akan dicapai.

LKPD yang digunakan belum memenuhi persyaratan didaktik, salah satunya yaitu menekankan pada proses untuk menemukan konsep-konsep dan mampu mengembangkan kemampuan berfikir kreatif peserta didik. LKPD juga belum memenuhi syarat konstruksi yaitu belum menyediakan ruang yang cukup untuk memberi keleluasaan pada peserta didik untuk menulis jawaban atau pemecahan masalah yang diberikan. LKPD hanya berisi sederetan pertanyaan yang harus dijawab oleh peserta didik, ini bisa menimbulkan rasa jenuh atau kurang menarik bagi peserta didik. LKPD harusnya memiliki kombinasi antara gambar dan tulisan atau yang memenuhi syarat teknis. Pentingnya penampilan LKPD yaitu untuk meningkatkan motivasi peserta didik dalam mengerjakan tugas yang ada di dalam LKPD.

Selanjutnya dilakukan analisis terhadap materi SMA kelas X semester genap. Pada analisis tersebut ditentukan pembatasan materi yang akan dimasukkan ke dalam perangkat yang akan dikembangkan. Pemilihan materi juga didasarkan pada diperlukan pemahaman konsep dan berpikir kreatif serta masalah-masalah kontekstual dalam kehidupan sehari-hari peserta didik. Selajutnya dilakukan identifikasi indikator yang memuat kemampuan berpikir kreatif peserta didik dalam memecahkan masalah. Indikator meliputi tiga komponen yaitu kefasihan, fleksibel dan kebaruan.

Selanjutnya dilakukan analisisis peserta didik, hasil yang ditemukan adalah peserta didik kelas X SMA ratarata memiliki usia 16-18 tahun, menurut teori Piaget dalam Ibda (2015), pada tahap ini peserta didik sudah mampu berpikir abstrak, memahami bentuk argumen, dan tidak dibingungkan oleh sisi argumen. Selain itu peneliti menemukan bahwa kemam-puan berpikir kreatif peserta didik masih rendah. Berdasarkan studi awal yang telah dilakukan dan didukung temuan dari Ismara, Halini, \& Suratman (2017). Hasil analisis diperoleh bahwa peserta didik belum difasilitasi untuk mengembang-kan keterampilan berpikir kreatifnya, sehingga perlu suatu solusi yaitu pengembangan perangkat pembelajaran matematika yang memfasilitasi kemampuan berpikir kreatif peserta didik.

Berdasarkan hasil analisis maka dibutuhkan solusi untuk permasalahan yang ditemukan yaitu dibutuhkan sebuah perangkat pembelajaran yang memperhatikan kurikulum, karakteristik peserta didik, dan tujuan pembelajaran agar terciptanya pembelajaran yang efektif dan menarik serta tersedianya perangkat pembelajaran matematika berupa silabus, RPP dan LKPD yang dapat memfasilitasi peserta didik untuk aktif menemukan konsep dan mampu meningkatkan kemampuan berfikir kreatifnya.

\section{Fase Prototipe (Prototyping Phase)}

Kegiatan yang dilakukan pada fase prototipe ini adalah merancang perangkat pembelajaran. Perangkat pembelajaran dikembangkan berdasarkan hasil yang diperoleh pada fase investigasi awal dengan mendesain pembelajaran dan membuat rancangan awal perangkat pembelajaran. Perangkat pembelajaran yang dikembangkan yaitu silabus, RPP, LKPD menggunakan penerapan model PBL terintegrasi keterampilan abad 21 untuk memfasilitasi kemampuan berpikir kreatif peserta didik. 
Silabus dikembangkan mengacu pada Permendikbud Nomor 103 Tahun 2014 dan Permendikbud No 22 Tahun 2016 karena pada kurikulum 2013 silabus telah disusun secara nasional oleh Kementrian Pendidikan dan Kebudayaan, maka tidak dilakukan pengembangan pada silabus hanya dikemas kembali dari segi identitas silabus, Kompetensi Inti (KI), Kompetensi
Dasar (KD), pembagian materi, Indika-tor Pencapaian Kompetensi (IPK), kegiatan pembelajaran, penilaian, alokasi waktu yang lebih jelas dan terperinci, juga sumber belajar untuk mempermudah guru dalam pelaksanaannya. Contoh kegiatan pembelajaran pada silabus yang telah dikembangkan pada Gambar 2.

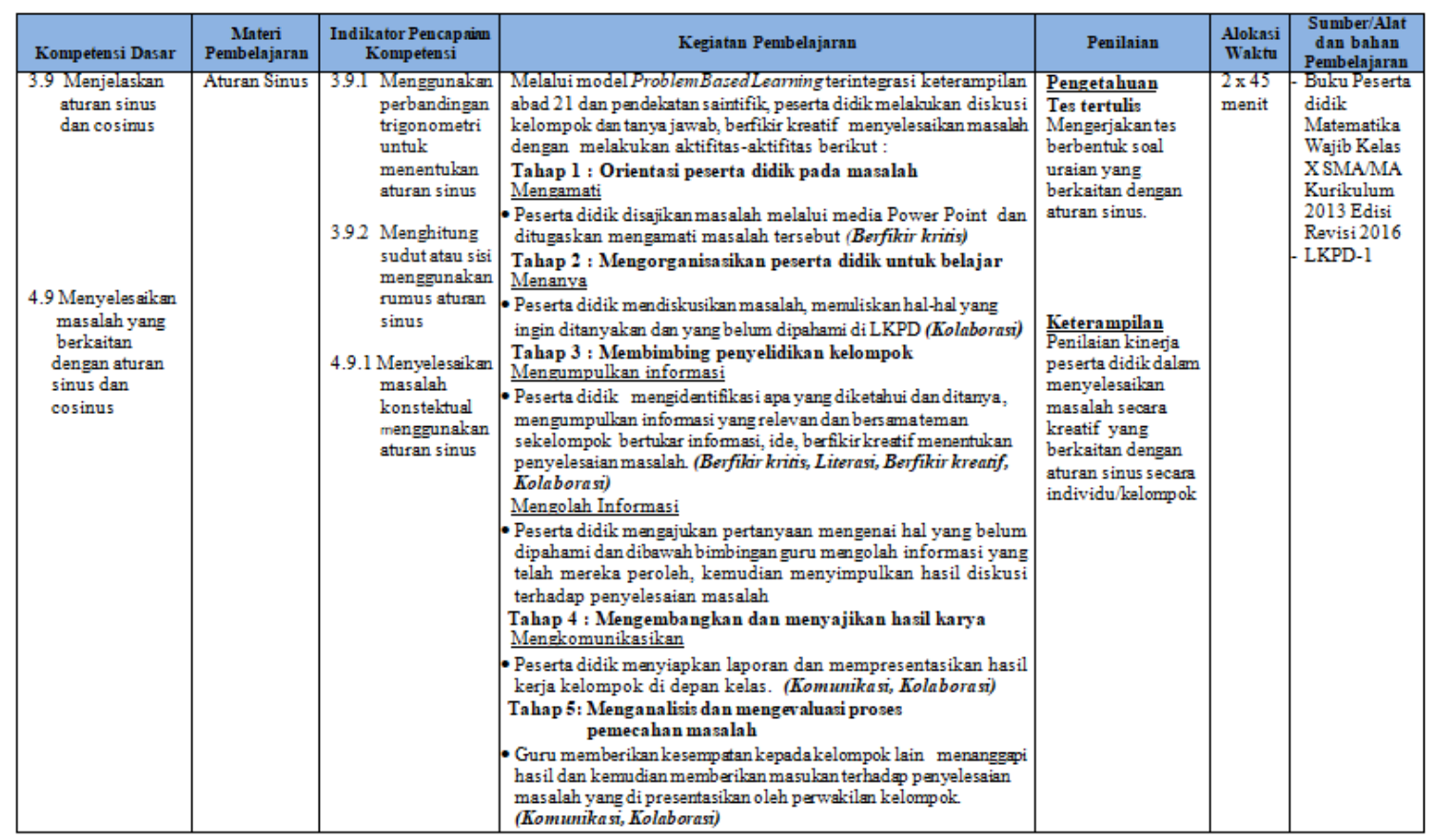

Gambar 2 Silabus yang dikembangkan

Pengembangan RPP mengacu pada silabus yaitu pada materi aturan sinus dan cosinus dengan menggunakan penerapan model PBL terintegrasi keterampilan abad 21 dan menggunakan pendekatan saintifik untuk memfasilitasi kemampuan berpikir kreatif peserta didik. RPP dibuat untuk lima kali pertemuan. Contoh kegiatan pembelajaran pada RPP yang telah dikembangkan pada Gambar 3.

Pengembangan LKPD dengan menerapkan fase-fase PBL terintegrasi keterampilan abad 21. LKPD dikembangkan secara rinci untuk memfasilitasi kemampuan berpikir kreatif berdasarkan rancangan yang telah disusun. Pengembangan LKPD meliputi bagian sampul dan bagian isi. Bagian sampul LKPD memuat judul, identitas peserta didik, tujuan pembelajaran, petunjuk pengerjaan LKPD dan gambar pendukung sesuai dengan materi yang akan dipelajari. Bagian isi LKPD dikembangkan berdasarkan tahapan model PBL yang terdiri dari Orientasi pada masalah, mengorganisasi peserta didik, membimbing penyelidikan, mengembangkan hasil karya, menganalisis dan 
DOI: https://doi.org/10.24127/ajpm.v10i2.3331

mengevaluasi proses pemecahan masalah. LKPD ini menggunakan pendekatan saintifik meliputi mengamati melalui kegiatan "ayo mengamati", menanya melalui kegiatan "ayo menanya", mengumpulkan informasi melalui kegiatan "ayo mengumpulkan informasi", menalar melalui kegiatan "ayo menalar", mengkomunikasikan melalui kegiatan "ayo mengkomuni-

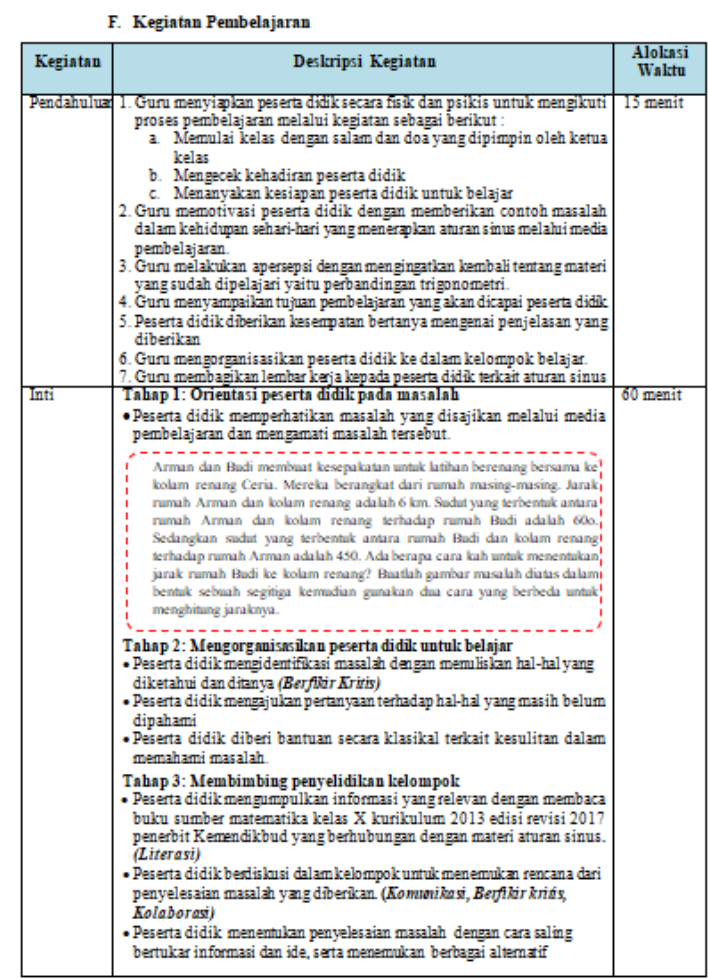

Gambar 3 RPP yang dikembangkan

\section{Fase Penilaian (Assessment Phase)}

Pada fase penilaian ini dilakukan validasi Silabus, RPP, dan LKPD yang telah dikembangkan. Validasi dilakukan oleh tiga orang validator, dua orang dosen ahli dan satu orang praktisi pendidikan. Saran dari validator digunakan untuk memperbaiki perangkat pembelajaran yang dihasilkan.

Aspek silabus yang dinilai validitasnya adalah aspek isi dan aspek konstruksi. Nilai rata-rata validasi silabus untuk setiap aspek dari ketiga validator disajikan pada Tabel 3. kasikan", dan "ayo berlatih". LKPD dibuat untuk lima kali pertemuan. Contoh kegiatan pembelajaran pada LKPD yang telah dikembangkan pada Gambar 4.

Silabus, RPP, dan LKPD yang telah dikembangkan dapat dilihat di http://bit.ly/PerangkatPembelajaranAtur anSinusdanCosinusReniYanuarni

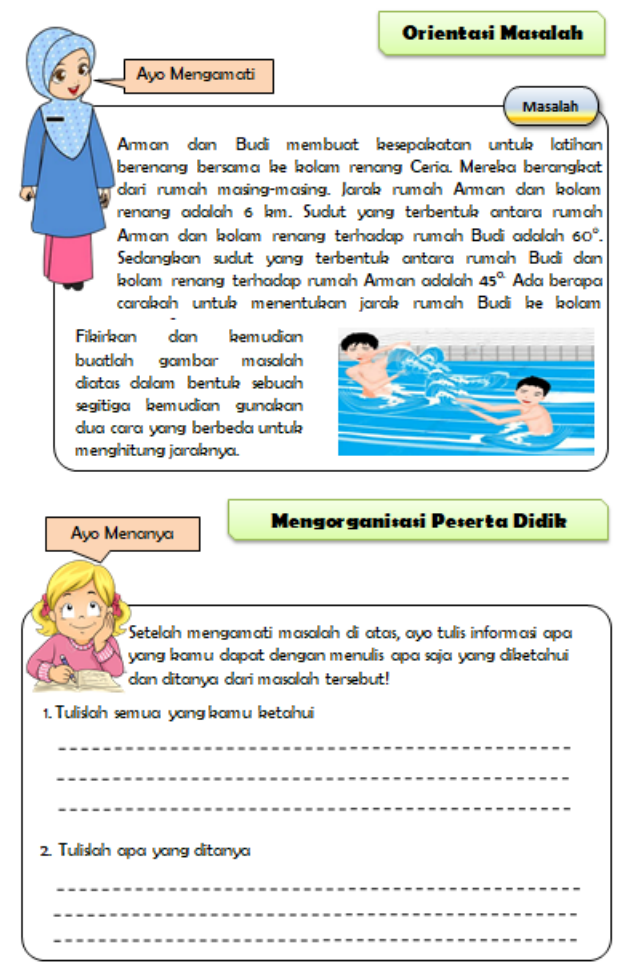

Gambar 4 LKPD yang dikembangkan

Tabel 3. Hasil validasi silabus

\begin{tabular}{llrl}
\hline No & $\begin{array}{l}\text { Aspek yang } \\
\text { dinilai }\end{array}$ & $\begin{array}{l}\text { Rata- } \\
\text { rata }\end{array}$ & Kriteria \\
\hline 1 & Isi & 3,88 & Sangat Valid \\
2 & Konstruksi & 3,55 & Sangat Valid \\
\hline & Rata-rata & 3,72 & Sangat Valid \\
\hline
\end{tabular}

Tabel 3 menunjukkan rata-rata validasi silabus secara keseluruhan dari ketiga validator yaitu 3.72. Berdasarkan nilai-nilai validitas dari ketiga validator, silabus yang dikemas kembali sudah memenuhi kriteria sangat valid. Pada aspek isi nilai rata-rata diperoleh 3.88 
dengan kriteria sangat valid, artinya silabus yang dikemas ulang telah sesuai dengan Permendikbud No. 68 Tahun 2014 tentang standar proses untuk satuan pendidikan dasar dan menengah, yaitu silabus merupakan suatu rencana pembelajaran pada suatu kelompok mata pelajaran tertentu yang mencakup $\mathrm{KI}, \mathrm{KD}$, materi pembelajaran, kegiatan pembelajaran, indikator pencapaian kompetensi, penilaian, aloksi waktu, dan sumber belajar.

Pada aspek konstruksi rata-rata diperoleh 3.67 dengan kriteria sangat valid, artinya kegiatan pembelajaran telah memfalitasi peserta didik sesuai indikator kemampuan berfikir kreatif dan sesuai dengan model PBL dengan pendekatan saintifik yang mengintegrasikan keterampilan abad 21.

Beberapa saran untuk perbaikan dari validator yaitu dalam kegiatan pembelajaran, integrasi keterampilan abad 21 dengan penerapan model PBL dan pendekatan saintifik supaya dideskripsikan secara rinci pada setiap kegiatan pembelajaran.

Aspek RPP yang dinilai validitasnya adalah aspek isi dan aspek konstruksi. Nilai rata-rata validasi ketiga RPP untuk setiap aspek dari ketiga validator disajikan pada Tabel 4

Tabel 4. Hasil Validasi RPP

\begin{tabular}{cccc}
\hline No & $\begin{array}{c}\text { Aspek yang } \\
\text { dinilai }\end{array}$ & $\begin{array}{c}\text { Rata- } \\
\text { rata }\end{array}$ & Kriteria \\
\hline 1 & Isi & 3.68 & Sangat Valid \\
2 & Konstruksi & 3.42 & Valid \\
Rata-rata Total & 3.55 & Sangat Valid \\
\hline
\end{tabular}

Tabel 4 menunjukkan rata-rata validasi RPP secara keseluruhan dari ketiga validator yaitu 3.55 dengan kriteria sangat valid. Aspek isi meliputi kelengkapan identitas RPP, kompetensi $\mathrm{KI}$ dan KD, kejelasan rumusan indikator pencapaian kompetensi, kejelasan rumusan tujuan pembelajaran dengan indikator pencapaian, kesesuaian materi pembelajaran, kesesuaian penilaian pembelajaran serta kesesuaian media dan sumber belajar dengan tujuan, model pembelajaran dan karakteristik peserta didik. Nilai rata-rata yang diperoleh dari ketiga validator untuk aspek isi adalah 3.67 dengan kriteria sangat valid.

Aspek kontruksi meliputi kesesuaian kegiatan pembelajaran dengan model PBL, keterampilan abad 21 dan indikator berfikir kreatif. Nilai rata-rata yang diperoleh dari ketiga validator adalah 3.42 dengan kriteria sangat valid. Hasil validasi tersebut menunjukkan bahwa RPP yang dikembangkan sesuai dengan prosedur penyusunan RPP yang termuat dalam Permendikbud No. 103 Tahun 2014 tentang pembelajaran pada pedidikan dasar dan pendidikan menengah dan Permendikbud No 22 Tahun 2016 tentang standar proses pada pendidikan dasar dan menengah, artinya RPP yang dikembangkan layak digunakan pada pembelajaran.

Berdasarkan nilai-nilai validitas dari ketiga validator, RPP yang dikembangkan sudah sangat valid dan sesuai aturan standar proses Permendikbud No 103 Tahun 2014 dan Permendikbud No 22 Tahun 2016. Namun terdapat beberapa saran untuk perbaikan dari validator yaitu dalam pengejaan, penskoran dan penulisan fakta dalam materi pembelajaran telah dilakukan revisi.

Pada LKPD yang dinilai validitasnya adalah aspek tampilan, isi, kesesuaian dengan syarat didaktik, syarat konstruksi dan syarat teknis. Nilai rata-rata validasi RPP untuk setiap aspek dari ketiga validator disajikan pada Tabel 5. 
DOI: https://doi.org/10.24127/ajpm.v10i2.3331

Tabel 5. Hasil Validasi LKPD

\begin{tabular}{clcl}
\hline No & $\begin{array}{c}\text { Aspek yang } \\
\text { dinilai }\end{array}$ & $\begin{array}{c}\text { Rata- } \\
\text { rata }\end{array}$ & \multicolumn{1}{c}{ Kriteria } \\
\hline 1 & Tampilan & 4.00 & Sangat Valid \\
2 & Isi & 3.37 & Valid \\
3 & Syarat & 3.60 & Sangat Valid \\
& Didaktik & & \\
4 & Syarat & 3.64 & Sangat Valid \\
& Konstruksi & & \\
5 & $\begin{array}{l}\text { Syarat } \\
\text { Teknis }\end{array}$ & 3.61 & Sangat Valid \\
Rata-rata Total & 3.64 & Sangat Valid \\
\hline
\end{tabular}

Tabel 5 menunjukkan rata-rata validasi LKPD secara keseluruhan dari ketiga validator yaitu 3.64, ini berarti LKPD yang dikembangkan telah memenuhi syarat-syarat LKPD yang berkualitas baik dan layak untuk diuji cobakan. Hal ini sesuai dengan yang dijelaskan (Lestari, Kurniawan, \& Fatmaryanti (2019) bahwa penyusunan LKPD harus memenuhi berbagai persyaratan yaitu syarat didaktik (penggunaan LKPD yang bersifat universal), syarat konstruksi (penggunaan bahasa, susunan kalimat, kosa kata, tingkat kesukaran dan kejelasan), dan syarat teknik (penyajian LKPD) dikarenakan keberadaan LKPD berpengaruh cukup besar dalam proses pembelajaran.

Untuk aspek didaktik nilai dari ketiga validator yaitu 3.60 dengan kategori sangat valid, ini menunjukkan bahwa LKPD yang dikembangkan sudah sesuai dengan kemampuan heterogen peserta didik, Namun setelah divalidasi peneliti melakukan beberapa revisi pada permasalahan yang diberikan, yaitu dengan menggunakan angka-angka menjadi lebih sederhana.

Pada aspek konstruksi memperoleh nilai 3.64 dengan kriteria sangat valid, ini artinya ketepatan penggunaan bahasa, susunan kalimat, kosa kata, tingkat kesukaran, dan kejelasan sudah tepat guna dalam arti dapat dimengerti oleh peserta didik. Syarat-syarat yang berkenaan dengan penggunaan bahasa, susunan kalimat, kosa-kata, tingkat kesukaran, dan kejelasan yang pada hakikatnya haruslah tepat guna dalam arti dapat dimengerti oleh pengguna yaitu siswa (Pranita, 2017). Dalam penyediaan ruang untuk jawaban peserta didik ada perbaikan, peneliti menambah ruang untuk jawaban lebih luas, yaitu pada LKPD-5.

Untuk aspek teknis nilai dari ketiga validator yaitu 3.61 dengan kriteria sangat valid. Artinya syarat teknis dalam penyusunan LKPD meliputi tulisan, gambar, dan penampilan sudah sangat baik. Tulisan pada LKPD menggunakan huruf cetak dan tidak menggunakan huruf latin atau romawi, menggunakan huruf tebal yang lebih besar untuk topik, bukan huruf biasa yang diberi garis bawah, menggunakan bingkai untuk membedakan kalimat perintah dengan jawaban peserta didik, mengusahakan agar perbandingan besarnya huruf dengan besarnya gambar serasi. Gambar yang baik untuk LKPD adalah gambar yang dapat menyampaikan pesan atau isi dari gambar tersebut secara efektif kepada pengguna LKPD. Penampilan LKPD yang menarik akan membuat peserta didik tertarik untuk belajar menggunakan LKPD. Ini sesuai dengan pernyataan Indriyani (2013) bahwa dalam LKPD bahasa disajikan dengan bahasa yang sederhana, komunikatif, dan mudah dipahami. Sehingga dapat dipahami peserta didik dengan mudah.

Aspek yang dinilai pada validasi soal-soal yang termuat di LKPD meliputi kelengkapan soal, kesesuaian soal dengan indikator berfikir kreatif dan kesesuaian bahasa dalam butiran soal. Rata-rata skor keseluruhan terhadap penilaian soal tes kemampuan 
berpikir kreatif yaitu 3.46 dengan kriteria sangat valid. Ketiga validator menyimpulkan bahwa soal dapat digunakan dengan revisi kecil yaitu mengganti angka dengan bilangan yang lebih sederhana.

Uji coba terbatas dilakukan untuk melihat praktikalitas LKPD yang dikembangkan kepada enam orang peserta didik kelas X SMA Negeri 15 Pekanbaru. Peserta didik dipilih berdasarkan hasil konsultasi dan saran guru bidang studi matematika. Peserta didik mengerjakan LKPD sesuai langkah kerja, kemudian peneliti memberikan angket respon peserta didik. Grafik ratarata hasil respon peserta didik seperti pada Gambar 5.

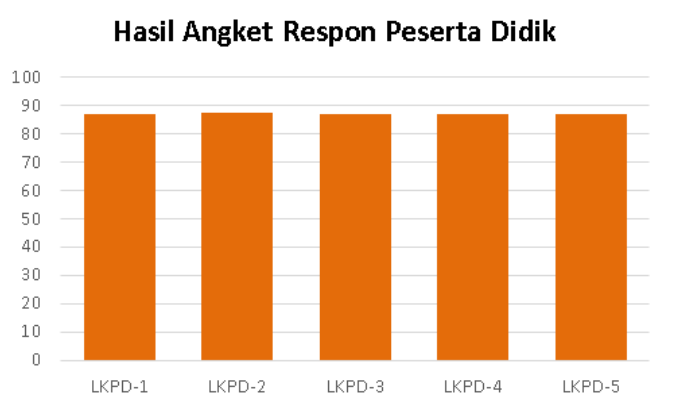

Gambar 5. Hasil angket respon peserta didik

Hasil angket respon peserta didik menunjukkan bahwa kriteria sangat praktis dengan rata-rata persentase 87.04\%. Berdasarkan hasil angket respon dan diskusi dengan peserta didik, secara keseluruhan LKPD sudah sangat baik, artinya peserta didik tidak merasa kesulitan dalam menggunakan LKPD. Menurut Afdareza, Yuanita, \& Maimunah (2020) perangkat pembelajaran dikatakan praktis jika responden menyatakan bahwa perang-kat pembelajaran dapat digunakan dalam pembelajaran yang ditunjukkan oleh hasil angket respon peserta didik dan penilaian oleh guru.
LKPD secara keseluruhan sudah sangat baik, namun ada beberapa saran dan masukan peserta didik. Komentar dan saran peserta didik ditunjukkan pada Gambar 6.

LKPO Sangat menarik. Penyajian masalah membuat peserta didik harus bisa memuh amí tiep hal yung diketaho warno yang menarik sehingga 'KPD tiduk membosanka Hanya sija ada ruang untuk mengisi jawaban Kurang sehingga haris imencan lamian lain untuk inengisi. jawaban

$$
\begin{aligned}
& \text { Pekanbaru, agushus } 2020 \\
& \text { Peserta Didik. }
\end{aligned}
$$

Gambar 6. Komentar dan Saran

Perbaikan dari Peserta Didik

Kegiatan selanjutnya dilakukan revisi LKPD berdasarkan hasil uji coba terbatas. Hasil uji coba terbatas menunjukkan bahwa LKPD yang dikembangkan sangat praktis. Namun ada beberapa kendala pada sebagian peserta didik ketika mengerjakan LKPD, yaitu misalnya pada awal peserta didik belum terbiasa menyelesaikan masalah dengan berbagai cara. proses pengerjaan lambat dan ketika menuliskan hal-hal yang belum dipaami, peserta didik merasa bingung hal apa yang harus dituliskan, karena belum terbiasa aktif bertanya dan hanya mendengarkan penjelasan guru. Kendala lain adalah waktu yang diberikan dalam mengerjakan LKPD, peserta didik kekurangan waktu karena belum biasa mengatur waktu yang efisien agar selesai sesuai dengan waktu yang diberikan. Masukan dan saran dari peserta didik pada LKPD yaitu supaya menambah ruang untuk mengisi jawaban dan tambahan waktu pengerjaan.

Tahapan selanjutnya adalah uji coba skala besar dan uji efektifitas, namun tidak bisa dilakukan karena adanya pandemi Covid-19. Seluruh sekolah SMA/MA di kota Pekanbaru 
melakukan pembelajaran online dari rumah sampai batas waktu yang belum bisa ditentukan. Untuk tahap desiminasi dan implementasi perangkat pembelajaran yang telah dikembangkan, diseminarkan pada seminar hasil penelitian di Program Pascasarjana Pendidikan Matematika yang dihadiri oleh dosen pembimbing, dosen penanggap dan peserta seminar.

Berdasarkan analisis hasil validasi yang telah diuraikan dan hasil angket respon peserta didik disimpulkan bahwa perangkat yang dikembangkan yaitu silabus, RPP, dan LKPD sudah memenuhi kriteria valid dan praktis untuk digunakan dalam pembelajaran matematika pada materi aturan sinus dan cosinus. Hal ini sejalan dengan pendapat Yuniarti, Riyadi, \& Subanti (2014) bahwa perangkat pembelajaran dikatakan baik apabila valid, praktis dan efektif. Penelitian ini juga sejalan dengan penelitian Sultoni \& Agustanto (2016) bahwa PBL berpendekatan saintifik mampu meningkatkan keterampilan berpikir kreatif peserta didik kelas XI MIA 4 MAN Temanggung pada materi trigonometri. Dengan demikian perangkat pembelajaran matematika yang menggunakan penerapan model PBL terintegrasi keterampilan abad 21 peserta didik SMA kelas $\mathrm{X}$ pada materi aturan sinus dan cosinus telah memenuhi kriteria valid dan praktis.

Dampak pengembangan perangkat pembelajaran ini diharapkan dapat bermanfaat bagi semua pihak, khususnya bagi peserta didik diharapkan dapat memfasilitasi kemampuan berpikir kreatif dalam menyelesaikan imasalah matematika dan kehidupan serta menjadi referensi guru dalam mengembangkan perangkat pembelajarani matematika.

\section{KESIMPULAN DAN SARAN}

Hasil penelitian yang telah dilakukan dapat disimpulkan bahwa perangkat pembelajaran berbasis keterampilan abad 21 dengan penerapan model PBL untuk memfasilitasi kemampuan berpikir kreatif peserta didik pada materi aturan sinus dan cosinus kelas X SMA memenuhi kriteria valid dan praktis.

Berdasarkan keterbatasan penelitian ini, peneliti memberikan saransaran bahwa penelitian ini hanya dilakukan sampai tahap uji coba skala terbatas, disarankan dilanjutkan untuk tahap uji coba skala besar pada peserta didik yang belum mempelajari materi aturan sinus dan cosinus agar diperoleh hasil penelitian yang lebih akurat.

Selain dari pada itu, pada penelitian pengembangan ini dibatasi perangkat pembelajaran yang terdiri dari silabus, RPP, dan LKPD. Peneliti menyarankan agar perangkat pembelajaran dapat dikembangkan untuk media pembelajaran.

\section{DAFTAR PUSTAKA}

Afdareza, M. Y., Yuanita, P., \& Maimunah. (2020). Development of Learning Device Based On 21st Century Skill with Implementation of Problem Based Learning to Increase Critical Thinking Skill of Studies on Polyhedron for Grade 8th Junior High School. Journal of Education Sciences, 4(2), 273284.

Akbar, S. (2013). Instrumen Perangkat pembelajaran. Bandung: Rosdakarya.

Bidasari, F. (2017). Pengembangan Soal Matematika Model PISA Pada Konten Quantity Untuk Mengukur Kemampuan Pemecahan Masalah Matematika Siswa Sekolah 
DOI: https://doi.org/10.24127/ajpm.v10i2.3331

Menengah Pertama. Jurnal Gantang, II(1), 63-78.

Hartini, T. I., Kusdiwelirawan, A., \& Fitriana, I. (2014). Pengaruh Berpikir Kreatif dengan Model Problem Based Learning (PBL) Terhadap Prestasi Belajar Fisika Siswa Dengan Menggunakan Tes Open Ended. Jurnal Pendidikan IPA Indonesia, 3(1), 8-11.

Ibda, F. (2015). Perkembangan Kognitif: Teori Jean Piaget. INTELEKTUALITA, 3(1), 27-38.

Indriyani, Y. (2013). Mengembangkan Konsep Sains dan Karakter Siswa melalui Pembelajaran Berbasis Bimbingan : Penelitian Tindakan Kelas di SDN kelas 1 Kebon Gedang Kota Bandung Tahun Ajaran 2012. Bandung: Universitas Pendidikan Indonesia.

Ismara, L., Halini, \& Suratman, D. (2017). Kemampuan Berpikir Kreatif Matematis Siswa dalam Menyelesaikan Soal Open Ended di SMP. Jurnal pendidikan dan Pembelajaran Khatulistiwa, 6(9), 1-8.

Juniantari, M. (2017). Pengembangan Perangkat Pembelajaran Matematika Berorientasi Pendidikan Karakter dengan model Treffinger bagi siswa SMA. Journal of Education Technology, 1(2), 71-76.

Lestari, L. T., Kurniawan, E. S., \& Fatmaryanti, S. D. (2019). Pengembangan Lembar Kegiatan Peserta Didik Berbasis Thinking Actively in Social Context (TASC) untuk Meningkatkan Kemampuan Mencipta pada Peserta Didik SMA. JRKPF UAD, 6(1), 10-16.

Maimunah, Yuanita, P., \& Solfitri, T. (2017). Pengembangan Perangkat Pembelajaran Melalui Pemecahan
Masalah untuk Meningkatkan Penalaran Matematis Mahasiswa Program Studi Pendidikan Matematika Jurusan PMIPA FKIP Universitas Riau. Jurnal AlKhwarizmi, 5(1), 13-24.

Muntaha, A., \& Hartono. (2013). Upaya Pengembangan Perangkat Pembelajaran Model Problem Based Learning untuk Meningkatkan Kemampuan Berpikir Kreatif. Journal of Primary Educational, 2(2), 115119.

Nieveen, N. (1999). Prototyping to Reach Product Quality. London: Kluwer Academic Publisher.

Pranita, S. (2017). Pengembangan Lembar Kerja Siswa (LKS) Matematika Berbasis Kontekstual untuk Memfasilitasi Kemampuan Berfikir Kreatif Siswa Sekolah Menengah Pertama Islam Terpadu Az-Zuhra Pekanbaru. Pekanbaru: Universitas Islam Negeri Sultan Syarif Kasim Riau.

Putri, A., Kartini, \& Yuanita, P. (2020). The Effectiveness of Learning Tools Based on Discovery Learning That Integrates 21st Century Skills to Mathematical Critical Thinking Ability in Trigonometric Materials in High School. Journal of Physics: Conference Series.

Putri, A., Roza, Y., \& Maimunah. (2020). Development of learning tools with the discovery learning model to improve the critical thinking ability of mathematics. Journal of Educational Sciences, 4(1), 83-92.

Redhana, I. W. (2019). Mengembangkan Keterampilan Abad ke-21 Dalam Pembelajaran. Jurnal Inovasi Pendidikan Kimia, 13(1), 2239-2253. 
DOI: https://doi.org/10.24127/ajpm.v10i2.3331

Sultoni, A., \& Agustanto, A. (2016). Upaya Peningkatan Kemampuan Berpikir Kreatif dengan Problem Based Learning Berpendekatan Scientific Pada Materi trigonometri. PRISMA, Prosiding Semianar Nasional Matematika IX (pp. 26-35). Semarang: UNNES. Retrieved from https://journal.unnes.ac.id/sju/inde k.php/prisma/article/view/21424

Supardi, U. S. (2015). Peran Berfikir Kreatif Dalam Pembelajaran Matematika. Jurnal Formatif, 2(3), 248-262.

Suriyani. (2015). Peningkatan Kemampuan Berpikir Kreatif dan Kemandirian Belajar Siswa melalui Pembelajaran Matematika dengan Pendekatan Open-Ended. Edu Science, 2(2), 28-34.

Susianna, N. (2014). Implementasi Keterampilan Abad 21 dalam Kurikulum 2013. Prosiding Seminar Nasional Pendidikan Matematika, Sains dan TIK STKIP Surya (pp. 1-13). Tangerang: STKIP Surya.

Umbaryati, U. (2016). Pentingnya LKPD pada Pendekatan Scientific Pembelajaran Matematika. PRISMA, Prosiding Seminar Nasional Matematika (pp. 217225). Semarang: UNNES. Retrieved from https://journal.unnes.ac.id/sju/inde x.php/prisma/article/view/21473

Yuan, X., \& Sriraman, B. (2011). An Exploratory Study of Relationships Between Students' Creativity and Mathematical Problem-Posing Abilities. In Sriraman, B., Lee K.H (eds) The Elements of Creativity and Giftedness in Mathematics. Advances in Creativity and
Giftedness. 1. doi:10.1007/97894-6091-439-3_2

Yuniarti, T., Riyadi, \& Subanti, S. (2014). Pengembangan Perangkat Pembelajaran Berbasis Masalah (Problem Based Learning) dengan Pendekatan Ilmiah (Scientific Approach) pada Materi Segitiga Kelas VII SMP Se-Kabupaten Karanganyar Tahun Pelajaran 2013/2014. Jurnal Elektronik Pembelajaran Matematika, 2(9), 911-921. 